\title{
Controlling Tools Use in Business Processes Management
}

\author{
Adriana Csikósová ${ }^{1}$, Katarína Čulková ${ }^{1}$, Mária Janošková ${ }^{2}$ \\ ${ }^{1}$ Technical University of Košice, Letná 9, Košice, Slovakia \\ ${ }^{2}$ University of Economics in Bratislava, Tajovského 13, Košice, Slovakia
}

\begin{abstract}
Controlling fulfils a leading position in the management. The paper deals with controlling tools use in business management. The research focuses on obtaining and evaluating data from a questionnaire survey on the current trends of controlling use in small and medium enterprises in selected region of Slovakia. The results show, predominantly in small companies, that there is no separate controlling departments or position of a controller. In medium enterprises, it is appropriate to optimize the already established controlling concept. The enterprise management will thus obtain information on effectiveness improving, and can immediately take measures to renew its planned business development.
\end{abstract}

Keywords - controlling, business management, small and medium-sized enterprise, Slovakia.

\section{Introduction}

Controlling is a phenomenon of the present, which we have known since the end of the last century, but in the new millennium, it received a new direction and content. Controlling is a modern efficient management tool aimed at helping the company achieve its goals [1].

DOI: 10.18421/TEM111-45

https://doi.org/10.18421/TEM111-45

Corresponding author: Katarína Čulková,

Technical University of Košice, Letná 9, Košice, Slovakia

Email: Katarina.culkova@tuke.sk

Received: 24 November 2021.

Revised: 07 February 2022.

Accepted: 12 February 2022.

Published: 28 February 2022.

(c) Br-Nc-ND]C 2022 Adriana Csikósová, Katarína Čulková \& Mária Janošková; published by UIKTEN. This work is licensed under the Creative Commons AttributionNonCommercial-NoDerivs 4.0 License.

The article is published with Open Access at https://www.temjournal.com/
Its task is to prevent possible surprises, timely anticipation of possible problems and take the necessary measures to reduce any negative phenomena.

It is a specific job of evaluating information. The task of controlling is not only process management; however mainly company-wide management with the use of obtained information about real processes. A necessity for controlling employees is not only knowledge of the whole company as a whole, but also its components [2]. The task of controlling is not only the evaluation of already performed events, but also anticipation, finding the most suitable direction to achieve business goals. Controlling is a set of specific tasks that are necessary and need to be completed. It is therefore essential to distinguish between the controlling function and the controller the person who is the holder of the controlling function [3]. Controlling is also the main task of management. Every manager also remembers the function of controlling [4]. There is no controller function in small and medium-sized enterprises; someone usually performs these tasks from the company's management or the head of the financial accounting department. The independent function of a controller exists in companies with up to about two hundred employees. He then takes over a responsibility for controlling tasks within the company. At present, controlling means a method of thriving business or managing success. Controlling is then effective and efficient if the organization achieves the goals it has set [5]. This is no longer possible today without the digitization of management processes [6].

The aim of the paper is to examine the position and benefits of controlling in small and medium-sized enterprises (SMEs) in a selected region of Slovakia, in order to find opportunities to increase effectiveness of this type of business. Small and medium-sized enterprises are an important part of a wide range of companies in most countries in the world. In the countries of the Organization for Economic Co-operation and Development (OECD) they represent more than $95 \%$ of the total number of all enterprises, with their share in employment 
averaging around $75 \%$ and their share in GDP up to $80 \%$. In the Slovak Republic, the quantitative share of small and medium-sized enterprises is comparable to developed countries, while their share in employment is on average more than $70 \%$. The small and medium-sized enterprise sector in Slovakia contributes to the creation of GDP by the volume of its production approximately $3 / 5$ of the total production volume.

\section{Present State of Problem Solving}

Opinions on controlling are not uniform in what exactly a given concept should express and what all controlling should be interested in [7]. Together with audit and benchmarking, controlling means a tool for the risk management [8]. According to Morales and Pezet (2012), controlling contributes also to the improving of the financial situation of the business [9].

In the most general sense of the word, we understand controlling as a method that aims to increase the effectiveness of the management system by constantly comparing the actual state of the business process with the desired state, then evaluating deviations and updating goals [10]. Bhosekar and Vyas (2012) state that the general definition of the concept of controlling itself takes place at three basic levels, namely [11]:

- Controlling as a business philosophy presents primarily on a theoretical level. It is a change of thinking in the field of business management, which consists of basic integrated parts planning, production, finance and marketing. These activities enter into a system of business organization, which first acts as a business entity in the sum of these parts.

- We understand controlling as a system of rules that helps to achieve the company's goals, prevents surprises and warns us in time of the dangers that require the implementation of appropriate management measures.

- Controlling as a company management project is a set of created elements and links, which by their manifestation fulfill the principles of the controlling system, i.e. that there are such means in the company that really take care of maintaining the desired state.

Controlling is the result of cooperation between the controller and the manager, contributing to the increasing of the business efficiency [12]. The process of setting goals, management and planning in the financial and performance area, we call controlling [13], [14], [15], [16]. Every company, regardless the size, should use controlling as a managerial activity. Gonos et al. (2016) use controlling as a process in industrial companies, helping implementation and realization of the business plan [17]. Controlling is a set of rules for achieving goals that serve to maintain the desired state and make a profit.

Controlling facilitates coordination in management, improves the management of the company's system, its tools facilitate control in various areas of responsibility. According to Písař and Bílková (2019), controlling serves to maintain the desired state in SMEs through innovation using [18].

Controlling is a management tool whose task is to coordinate the planning, control and provision of an information database in order to work to improve business and financial results [19].

When defining the term controlling, we come across two important facts. The first is the fact that controlling is a practical rather than a theoretical discipline [20]. Due to its nature, it was difficult to deal with controlling in the academic environment [21]. It can even be stated that no set of academic knowledge has been established on which scientists could base the definition of controlling [22]. The second fact is the understanding of controlling, which is different in Anglo-Saxon countries from those in German-speaking countries. There are several important definitions of controlling in the available literature and in this concept; it has several meanings and various annotations [23].

In the Anglo-American science of management, it represents controlling in addition to planning, organizing main management function. An essential role of management is to manage the company as a system and gain control over it. The term controlling came to Europe for the first time after the Second World War, while controllers appeared almost exclusively in subsidiaries of American companies. In the mid-1970s, a decline in sales also added to the consumer goods markets. All this brought to the forefront of interest for Europe at that time a relatively new, but faster expanding position of a controller. In 1974, almost $90 \%$ of the largest German companies already had controlling in their organizational structure. The German professional literature has the institutional definitions of the term to expand from a purely functional point of view. Individual authors describe the controller as an auxiliary instance, which provides its own holders with functions of controlling, management, services. Other authors believe that the controller itself is a controlling function [24]. It remains common for both worlds that, as in German controlling and managerial accounting, the importance of information for the management and decision-making of the company's management is emphasized, primarily financial information. 
Due to the non-existence of a corresponding term with the same meaning and content, the professional German literature included the word controlling in German. Controlling began to reach European countries, and especially Germany, only with the gradual influx of American companies and their branches. During the 60's, German companies were provided with the introduction of controlling, in the 70 's, larger companies began to create jobs, respectively separate controlling units [25]. The main guideline is within the scope of control theory. Controlling attributes secondary guidance, the task of which is to guide and manage the activities of specialized subsystems in the control system and to provide information, consisting of the following subsystems: value, planning, control, information, organizational and personnel management system.

Kruml et al. (2015) and Mundy (2010) deals with controlling as one of the most important approaches of business management with possibilities for interconnection with process management, especially in SME's [26], [27]. According to Schmiedel et al. (2014) despite a common understanding that culture is an important element in BPM efforts, there is a dearth of theoretical and empirical research on culture as a facilitator of successful BPM [28]. IT and BPM systems is at most the aspect of Business Process Management. In fact, Business Process Management (BPM) is a comprehensive system for managing and transforming organizational operations [29]. According to Eldridge et al. (2013), controlling tools help the organizations making business in uncertain environment through formal and informal control systems [30].

Several authors studied controlling tools used in different industrial sectors, as for example [31] in area of gas transportation, [32] in business with insurance, [33] in telecommunication area, [34] in logistic area and [35] in manufacturing companies. Number of authors studies use of controlling tools in small enterprises. For example, Gottlieb et al. (2021) studied small family firms in area of farm business, finding negative state of small enterprises using control practices [36]. Heinicke (2018) researched possible use of controlling to performance measurement systems in SMEs, finding it is still scarce and indicating SMEs may benefit from the use of sophisticated control systems [37]. Senftlechner and Hiebl (2015) made a comprehensive review of empirical literature on use of controlling tools in SMEs, finding in past decade the academic interest in this area increased and management accounting and control seem to be generally less relevant to family businesses than to non-family businesses. Presented review show there is a little research of the controlling tools using from the regional view, when results of the presented paper provide the possible approach.

\section{Methodology}

Based on a review of the literature, through the systematic and detailed processing of individual knowledge in the field of controlling, which follows each other, the main goal is to examine the use of controlling and its tools in managing business processes, finding out the reasons for possible nonuse in small and medium-sized enterprises. To meet the main goal, we have set the following sub-goals:

1. Examine different approaches to understanding, time dimensions of controlling and position in the management process, controlling tools in different phases.

2. Analyze small and medium-sized enterprises; verify the methods and use of controlling in small and medium-sized enterprises of the selected region based on the implementation of own research [38].

3. Evaluate the results of research and draft recommendations for companies in the selected sector.

To achieve the main one, the paper is a survey through a questionnaire survey with selected research questions. Hypotheses:

- H1: We assume that a separate position of a controller exists in all companies with a foreign ownership structure.

- H2: We assume that more than $50 \%$ of small and medium-sized enterprises use controlling tools in corporate management.

- H3: We assume that the application of controlling and its tools is more a matter of medium-sized enterprises than small enterprises.

- H4: We assume that small and medium-sized enterprises in the chosen region focus mainly on financial indicators in corporate governance.

- H5: We assume that the main problems in introducing controlling into the management of small and medium-sized enterprises are the lack of qualified staff and insufficient knowledge of this modern management system.

The questionnaire survey took place in the months of November 2020 to February 2021. The research hold through an online questionnaire using the Survio web application. The research focused on the use of controlling tools in small and medium-sized enterprises in the Prešov region, the questionnaire survey addressed 200 enterprises that have their registered office in the Prešov region. We sent the questionnaire by e-mail to the addresses of the statutory offices or to the economic departments of the companies addressed. Out of the total number of companies contacted, 23 companies responded to the questionnaire and participated in the research. The 
total return of the answers in the questionnaire survey reached the level of $11.5 \%$.

The present state of controlling tools using in the management researched in SMEs in a chosen region of Slovakia - Prešov region, since it presents the second biggest region of Slovakia, neighbor with Poland, Ukraine and other regions of Slovakia. Industry in the Prešov region presents a diverse metalworking, woodworking, food, electrical, engineering, chemical, and textile and clothing industries. Small and medium-sized enterprises have the highest representation in the Prešov region. Enterprises with up to 49 employees represent more than $97 \%$ of the total number of enterprises. Large companies with 250 or more employees make up less than $1 \%$ of the total. Small and medium-sized enterprises (SMEs) in Slovakia began only after 1990 with the coming privatization of state property. Small and medium-sized enterprises are showing a sharp increase, also due to the following factors:

- Disintegration of state-owned enterprises;

- Return of confiscated property to citizens within the framework of restitutions;

- Market liberalization, demand for goods and services, inflow of foreign capital.

As of 31 December 2019, 77,942 active business entities belonging to the category of small and medium-sized enterprises (including microenterprises) registered in the register of organizations of the Statistical Office of the Slovak Republic in the Prešov region. Of interest is their dynamic year-onyear increase of $8.0 \%$. In the Prešov region, microenterprises form the most numerous size categories with $97.4 \%$ of the total number of active business entities. Small and medium-sized enterprises represented in the Prešov region by only $2.6 \%$. $21.8 \%$ of all small and medium-sized enterprises in the Prešov region are concentrated in the Prešov District and $13.6 \%$ in the Poprad District. The District of Prešov presents a center of business activities based on the number of active business entities. Low numbers of small and medium-sized enterprises are in the districts of Medzilaborce (1.0\%), Stropkov (2.4\%) and Levoča (3.4\%).

The questionnaire consisted of two parts. In the first part, we focused on finding out the basic data about the company, such as the legal form of business, the number of employees, the focus of the industry and the length of existence of the company. In the questionnaire survey, we focused on the category of small and medium-sized enterprises that have their headquarters and perform their business activities in the Prešov region. Therefore, in the following Table 1 we divided the individual companies that participated in the questionnaire survey. Such a division of enterprises based on the criteria for the classification and categorization of small and medium-sized enterprises. Seventeen small enterprises and 6 medium-sized enterprises from the Prešov region responded to the questionnaire and participated in the survey. The basic criterion for this division was the number of employees in individual companies (Table 1).

Table 1. Review of researched enterprises according to the volume

\begin{tabular}{|l|c|c|c|}
\hline \multicolumn{1}{|c|}{ Enterprise } & Small & Medium & Total \\
\hline Number & 17 & 6 & 23 \\
\hline \% rate & 73.91 & 26.09 & 100.00 \\
\hline $\begin{array}{l}\text { Average employees } \\
\text { number }\end{array}$ & 27 & 63 & - \\
\hline Production business & 14 & 6 & 20 \\
\hline $\begin{array}{l}\text { Non-productive } \\
\text { business }\end{array}$ & 3 & 0 & 3 \\
\hline
\end{tabular}

Limited-liability companies participated in the largest share of the questionnaire survey, specifically with the number of 16 , which in total represents a value of less than $70 \%$. Four joint-stock companies and three self-employed persons also took part in the survey. Other forms of business did not participate in the questionnaire survey. In terms of the sectoral structure of the surveyed companies, three business entities, with a percentage value of $13 \%$, were from the nonmanufacturing sector. Twenty companies carry out their business activities in the manufacturing sector. Nonmanufacturing included one privately employed person, one joint-stock company and 1 limited liability company. We can conclude that companies engaged in production activities are more interested in controlling. Companies that have been operating on the market for a longer period of more than 10 years, namely 11 companies, which represents $47.82 \%$, hold the largest share of the addressed companies. Other companies are represented in the same way, with a number of six and a percentage value of 26.09.

\section{Results}

As for the research of controlling state worldwide, we made the research using the database of the company Controller - Institute and Contrast Consulting Prague in Czech and Slovak companies. Such a database was chosen deliberately, given the nature of the problem and the narrowly defined questionnaire survey, which assumed the existence of a controlling department in the surveyed companies, which this database guarantees. The recipients of the research were the heads of the controlling departments of these companies. Total number of 748 companies received the questionnaire. Only 59 completed questionnaires returned, of which only 56 
questionnaires were suitable for evaluation. The return rate of the questionnaires thus represented less than $8 \%$. In general, this return is as quite low, mainly due to the narrow focus and "sensitivity" of the data. If we compare this return with similar research carried out in the field of controlling in the Czech Republic, Germany and Austria, the achieved return will start to appear in a slightly different light. Controller - The Institute reports a maximum return of $10 \%$ for similar research. Returns on the performed research in the field of controlling in German-speaking countries in the years $1976-1993$ ranged from $7 \%$ to $47 \%$. However, these researches were much more general.

The following concepts are most often used in the practice of Czech and Slovak companies as systems for measuring business process performance: Balanced Scorecard (BSC), Activity Based Costing (ABC), European Foundation for Quality Management (EFQM), Six Sigma, Performance Pyramid, Benchmarking, System both Du Pont and Value Based Management (VBM) indicators. 15\% of the participating companies stated that they used one of the mentioned performance measurement systems also for measuring the performance of controlling processes. Whether or not they try (as later qualitative research has proved) to, more or less successfully, apply the established methods of evaluating business performance. In $90 \%$ of cases, presenting companies with foreign capital that took over the concept from the parent company, but it was not a comprehensive methodology for evaluating the performance of controlling processes. The performance measurement systems listed included $\mathrm{ABC}$, BSC, Benchmarking and Value Based Management. An effort exists to evaluate the performance of controlling using our own specific indicators. In terms of the size of the companies examined these were only medium and large companies, with the share of large companies representing $75 \%$.

Of the companies surveyed, $18 \%$ did not use any such system, but were convinced that one of these systems could be applied in the context of their companies, namely $\mathrm{BSC}, \mathrm{EFQM}, \mathrm{ABC}$ and Benchmarking. In addition, in this case most of these companies had a foreign owner. $11 \%$ of the analyzed companies are considering the introduction of BSC, Benchmarking and Value Based Management systems. The results of the research pointed to the fact that almost half (48\%) of companies do not use any system to measure the performance of controlling processes. In addition, they do not consider its implementation. $16 \%$ of heads of controlling departments in the surveyed companies are convinced that it is not possible to objectively measure the performance of controlling. $4 \%$ of respondents chose the last option, which was in the nature of an open-ended question. They stated that they had no experience with similar systems or that it was not possible to define preferences here. The following Figure 1 reveals the barriers to evaluating the performance of controlling processes.

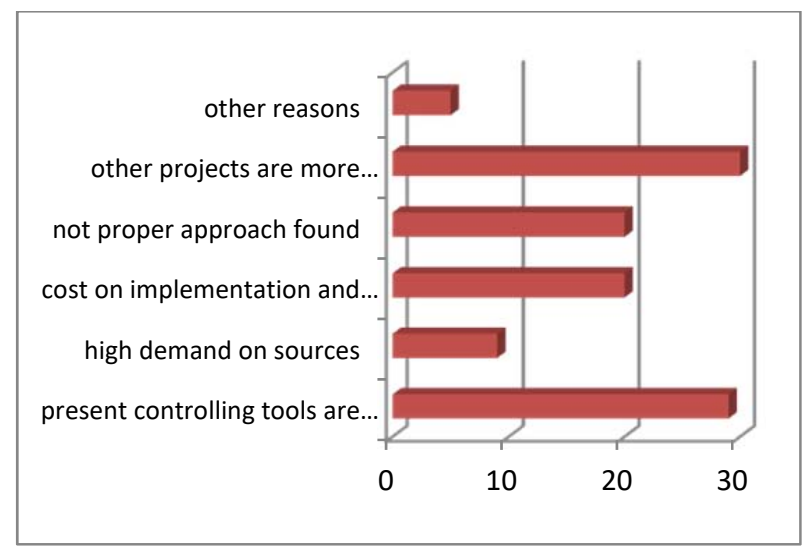

Figure 1. Reasons for the controlling absence in business evaluation

As we can see from the graph, the results suggest that for almost a third of the companies surveyed, their current controlling tools are sufficient and there is no need of other performance measurement systems. $9 \%$ of companies stated the high demands of such systems on time and financial resources as the reason for the absence of systems for measuring the performance of controlling processes. One-fifth of companies see the barrier to implement these systems in the cost of implementing and maintaining the system. Another fifth of the surveyed companies has not yet been able to find a suitable approach to measuring controlling performance. For $30 \%$ of the surveyed companies, other projects were a priority. Among other reasons for the absence of evaluations of controlling performance, they mentioned the group policy of the company, which prioritizes other projects and perceives controlling only as a support tool.

In science and in practice, the issue of performance and optimization of controlling is increasingly the focus of professional publications, controlling conferences and knowledge transfer programs abroad. Unfortunately, the previous description still does not apply to the situation in Czech and Slovak companies. As the results of surveys have shown, the issue of performance evaluation and optimization of controlling processes is still not on the "agenda." Based on quantitative and qualitative research, the evaluation of company performance and business processes is one of the most important controlling tasks in the practice of our companies, but companies do not yet attach great importance to performance evaluation and optimization of their controlling processes. This may be partly because Slovak and 
Czech companies often take over the controlling methodology from the parent foreign company and apply it for several years without adapting it to the specific conditions and factors of their surroundings. This fact also implies the need to evaluate and optimize controlling performance.

The results regarding the research of controlling position in SMEs in Prešov region are as follows:

In connection with hypothesis $\mathrm{H} 1$ : We assume that the independent position of the controller exists in all enterprises with a foreign ownership structure, in the next part of the questionnaire we found out what the ownership structure of enterprises is. We further examined whether there is any connection in the case of the establishment of a separate position of a controller, any connection between the Slovak company and a company with foreign representation. Of the surveyed companies that participated in a questionnaire survey, 19 of them stated a purely Slovak property structure and 4 companies with a foreign representation.

In the second part, we focused on finding out the existence of the position of a controller (see Table 2) respectively non-use of controlling or some of its tools in corporate management, as well as finding out attempts of possible implementation of controlling into management, reasons for not using the controlling system. Three companies stated that they had the position of the controller, which represents more than $13 \%$ of all companies. In almost $87 \%$ of companies, the position of the controller does not exist yet at all. In small businesses, the owner, sometimes in cooperation with the economist, mainly performs the controlling tasks. It is clear from this that in smaller companies controlling is not yet fully domesticated.

Table 2. Controller position in the analyzed enterprises

\begin{tabular}{|c|c|c|}
\hline & Number & $\%$ rate \\
\hline Yes & 3 & $13.04 \%$ \\
\hline No & 20 & $86.96 \%$ \\
\hline Sum & 23 & $100.00 \%$ \\
\hline
\end{tabular}

As further follows from the research, the position of the controller exists only in medium-sized companies with foreign participation. These companies have already used controlling. For companies without foreign participation, the use of controlling is no longer obvious. This was also confirmed as this position is established in one joint stock company and in two limited liability companies. All three companies indicated a foreign ownership structure. We can state that hypothesis $\mathrm{H} 1$, which assumed that a separate position of the controller was established in each company with a foreign ownership structure, is not confirmed.
The following questions of the questionnaire were connected with hypothesis $\mathrm{H} 2$ : We assume that more than $50 \%$ of small and medium-sized enterprises use controlling tools in corporate management and hypothesis H3: We assume that the application of controlling and its tools is more a matter for mediumsized enterprises than small enterprises. These two hypotheses are closely related. In the following question of the questionnaire, we structured the interviewed respondents according to whether they are currently carrying out any controlling activities or not (see Figure 2).

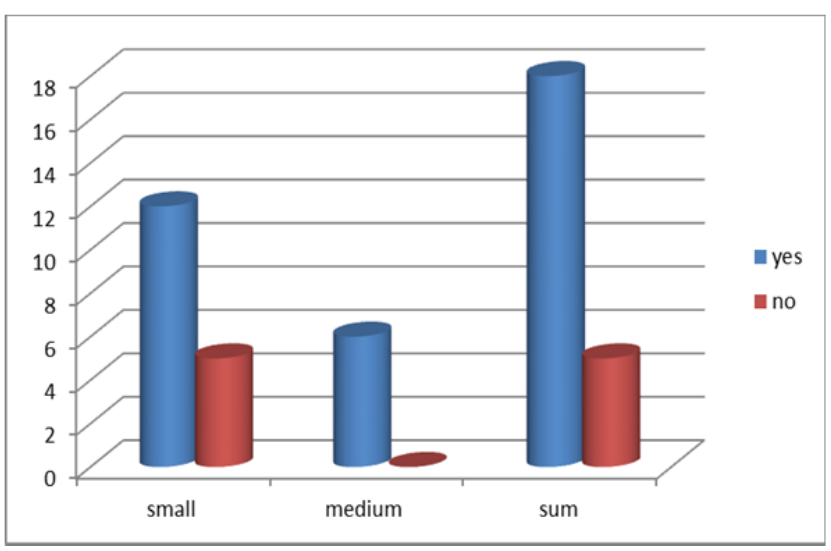

Figure 2. Use of controlling tools

As Figure 2 shows, less than $80 \%$ of all businesses reported controlling apply tools in corporate governance. The rest of the businesses does not implement controlling. All medium-sized enterprises (6) reported the use of controlling tools (H3). The situation is different for small businesses, and we have found from research that not every third small businesses deal with the issue of controlling.

Table 3. Controlling position in the organization structure

\begin{tabular}{|l|c|c|}
\hline & Number & $\%$ rate \\
\hline No controlling & 5 & 21.74 \\
\hline $\begin{array}{l}\text { Only basic tools without special } \\
\text { expert }\end{array}$ & 12 & 52.16 \\
\hline $\begin{array}{l}\text { Controlling done by one } \\
\text { employee }\end{array}$ & 4 & 17.40 \\
\hline $\begin{array}{l}\text { Controlling done by several } \\
\text { employees }\end{array}$ & 0 & 0.00 \\
\hline Separate controlling department & 2 & 8.70 \\
\hline
\end{tabular}

It is further clear from the following Table 3 that the existence of a separate controlling department is one of the least used integrations of controlling in the organizational structure. Such a separate controlling department exists in less than nine percent of all surveyed companies. In every sixth company, one employee from an unspecified department performs controlling. As mentioned above, the fifth company does not use controlling. The majority of companies have integrated basic controlling tools without a specialized expert. 
Based on the obtained results, we can state that hypothesis H2, which assumed that corporate governance used a controlling tool by more than $50 \%$ of small and medium-sized enterprises, is confirmed. Hypothesis $\mathrm{H} 3$ is also confirmed, as we found out by processing the obtained data that all medium-sized companies that participated in the questionnaire survey use controlling tools.

Other questions from the questionnaire related to hypothesis H4: We assume that small and mediumsized enterprises in the Prešov region focus mainly on financial indicators in corporate management. $21.74 \%$ of companies do not use any controlling tools. As we can see from Graph no. 8, less than half of the surveyed companies focus mainly on financial controlling, where they use planning and various reports from economic financial analyzes, which are based mainly on internal accounting and various sources that are focused on the financial health of companies. More than a third of the surveyed companies use accounting outputs, budgets as well as calculations, which are part of cost controlling, focused mainly on cost management, as illustrated in Figure 3.

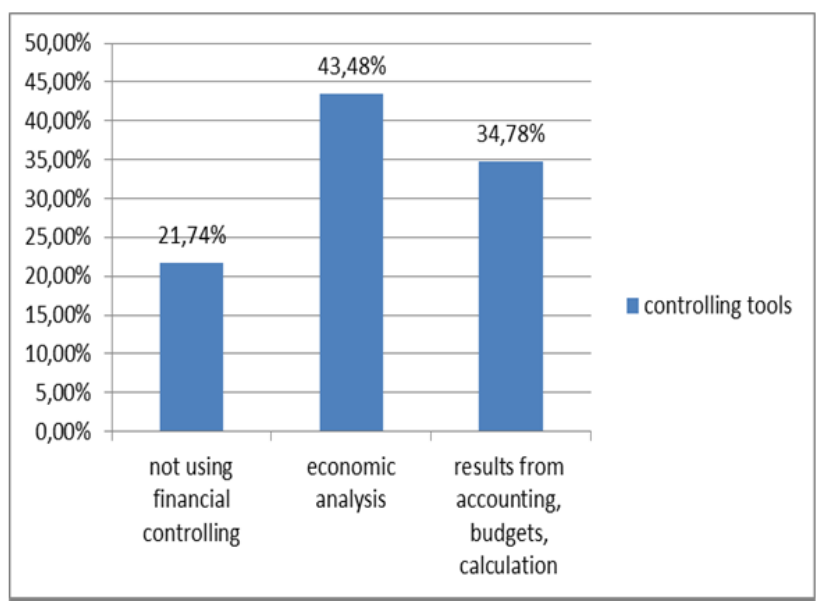

Figure 3. Type of controlling tools

Figure 4 shows us the areas of focus of controlling. The companies surveyed, which answered the previous question in the affirmative, had the opportunity to specify the areas in more detail here focus of controlling in their corporate management, they could choose several options when answering.

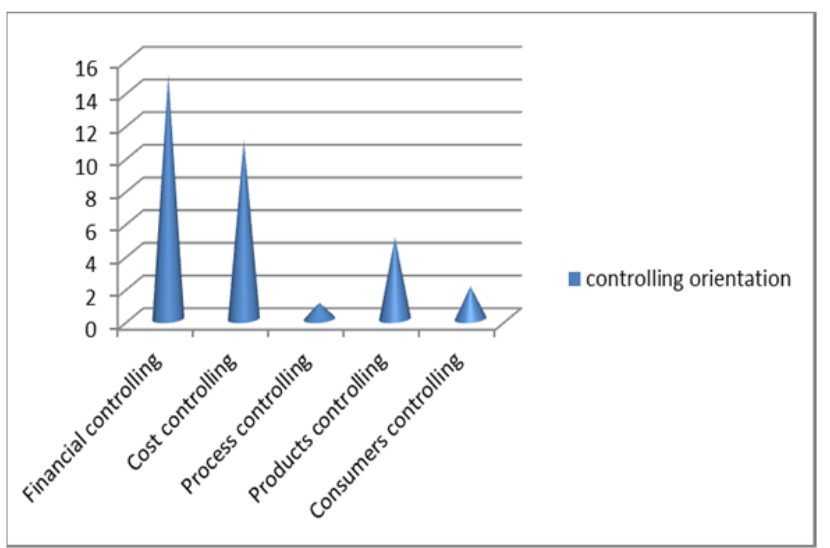

Figure 4. Orientation of controlling in the management

The data we obtained from the surveyed companies pointed to the fact that most companies stated that they monitor financial indicators and financial results, which provide them with a comprehensive report on the overall management and financial health of their company. They immediately followed by the area of cost controlling, which significantly confirmed the previous question from the questionnaire. Five of the surveyed companies mentioned product focus, two companies focus on customers and only in one case procedural focus of controlling was mentioned. Based on the results obtained, we can conclude low awareness on process management in small and medium-sized enterprises. Hypothesis $\mathrm{H} 4$ that small and medium-sized enterprises in the Prešov region focus mainly on financial indicators in corporate governance has not been confirmed.

In connection with the last hypothesis H5: We assume that the main problems in introduction of controlling into the management of small and medium-sized enterprises are a shortcoming qualified staff and insufficient knowledge of this modern management system, companies should specify the main issues encountered during implementation controlling also in its subsequent use. Only companies that use controlling (out of the total number of positive answers 18 , small enterprises were 12 and medium-sized 6) could give more answers.

Based on research results, increasing software costs is the most common controlling implementation problem for small and medium-sized businesses. Only less than a third of companies do not see the problem in being sufficiently qualified staff to perform the function of the controller. As follows from Figure 5, the majority of the surveyed companies also do not know enough about this modern management approach. For every fifth company, implementation is a problem in terms of time. Most medium-sized companies perceive the problem of implementation in terms of financial and personnel. 


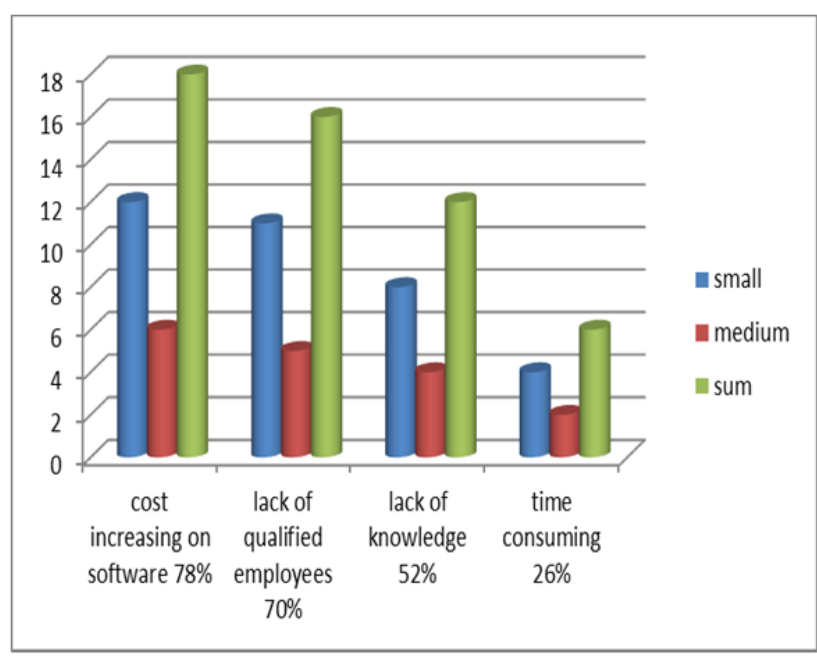

Figure 5. Main obstacles for controlling implementation

Other reasons given by the respondents for small and medium-sized enterprises were the costs of the implementation itself (7), but also the costs of a possible external consultancy firm (6). In addition to these financial barriers, they also specified possible problems from the point of view of the organization, where they indicated the long implementation period (6) and the necessary change in the company's information system used (4). In solving the second part of hypothesis H5, we also evaluate question no. 8 from the questionnaire. When asked if they had ever tried to introduce a controlling system into the company's management in the past, more than a half of the respondents answered in the negative (see Table 4). By a deeper analysis of the data obtained from the interviewed respondents, we found that small companies did not implement the controlling system.

Table 4. Enterprises trying to implement controlling

\begin{tabular}{|c|c|c|}
\hline & Number & \% rate \\
\hline No & 13 & 56,52 \\
\hline Yes & 10 & 43,48 \\
\hline Sum & 23 & 100,00 \\
\hline
\end{tabular}

Based on the results of the research, we found that for all companies that use controlling tools, increased software costs were a significant implementation problem. At the same time, we can state that there is still not enough information about the awareness of controlling in the conditions of small and mediumsized enterprises. Hypothesis H5, which assumed that the lack of qualified staff and insufficient knowledge of this modern management system will be the main problems in the implementation of the controlling system in the corporate management of small and medium-sized enterprises, was not confirmed.

\section{Discussion}

The return on such questionnaires is still low. This is despite the fact that the surveyed companies had an opportunity to learn about the results of the questionnaire survey, where they could at least take something for their management of their company, respectively. It can be stated that there is no general interest in such research. This may be associated with a kind of reluctance and distrust of the statutes and executives of companies to file respectively disclose sensitive data. During the research, we contacted several companies and it was necessary to divide them by size. It is clear from the results of the research that no large company participated in the survey.

Predominantly in small companies, there are no separate controlling departments or a separate position of the controller. This is mainly due to the limited capacity of small businesses, as mainly the owners, often in cooperation with a financial accountant or economist, perform the controlling tasks in them. However, accounting does not provide them with answers to the questions of how to: optimize costs, finance projects, create budgets, and plan financial flows. The performance of controlling requires special knowledge and skills that force management (leaders) to re-learn, which requires some effort (and time). Owners or managers often do not have the necessary expertise or qualifications to perform controlling tasks. For these companies, it would be reasonable to introduce controlling in the form of outsourcing services, or use the services of an external controller, who has extensive experience not only in controlling, but also in other companies or various business sectors. He also has access to various advanced IT tools which would be expensive for small businesses. A possible disadvantage of an external controller is that he must first be acquainted with the company; get to know its strategy, vision, and goals. Moreover, because he is not always in the workplace, he is in charge of several companies; he will never reach the level that an internal worker can.

In the case of medium-sized companies, it is appropriate to optimize the already established controlling concept, set up their own controlling department or department, using controlling software offered by various software companies, or interconnecting controlling solutions and reporting with an already existing information system. We can mention the known MonetABC, Oracle, Dominant, Abru, SAP or Gist. The advantage of such an implementation is a situation where the company does not have to create a finance department or hire expensive financial specialists or a team of analysts when using a software company. It is enough to recruit employees who would be in charge of the 
controlling department from a number of existing employees who know the company sufficiently. Furthermore, to use methodical guidance or supervision from a software company in the implementation of an economic information system or controlling software, or to participate in professional training and seminars controlling solutions will thus provide management with information on the current state of the company. They contribute to the prediction of the economic situation, but also to plan. They continuously monitor goals, financial performance and performance to help owners and management respond flexibly and quickly.

Small and medium-sized enterprises should implement and regularly evaluate the current state of their business, analyze their strengths and weaknesses, perform a SWOT analysis, based on which they will learn how they are doing [39].

It is no less important to perform a financial economic analysis, use and evaluate plans, budgets or calculations when managing business processes. Compare the results with plans that need to be evaluated later in management, link cost and revenue calculations to the plan is also of great importance. Equally important in managing business processes is the use of budgets. In general, the budget does not only represent a kind of forecast of the financial statements, but it determines all the main areas of activity of companies, it describes them in terms of financial, organizational and operational. It defines the planned activities with their results at all levels. Key employees in cooperation with management should prepare it. During the implementation of the budget, which will take place during the financial year, it is appropriate to analyze the results already implemented and compare them with the approved budget. Based on these data, subsequently process and prepare for management once a month, control reports that point to the current state and forecasts. Then there is the need to analyze any observed deviations and predict their impact on the current situation in the company. The company's management will thus obtain information on deviations from the budget, and their possible impact on the company, assess their significance for the company and can immediately take measures to renew its planned route of business development.

\section{Conclusion}

At present, thanks to the arrival of multinational companies in Slovakia, a popular management technique called controlling is becoming a modern tool for managing the economy, even in small and medium-sized enterprises. Properly and actively applied controlling is a way to increase the performance of the company, because its role is not to manage real processes in the company, but to manage the entire company through information about real processes. However, small and mediumsized enterprises often forget to implement tools in their business processes that would help them to identify possible causes of their problems in time. They mistakenly believe that it is sufficient if only a control tool is set up in corporate management. If the company's management no longer tries to identify and reveal the causes of possible problems during the process, it is quite likely that it will return to them in the form of a problem that has already arisen. Thanks to the introduction of properly functioning controlling, companies can prevent various crises in the future. Through the application of controlling methods and tools, management can keep their company under control so that its performance is constantly growing. The introduction of controlling will thus help not only to identify possible pitfalls, but also to put in place effective measures in time to prevent them in the future. In addition, small and medium-sized enterprises can obtain quality production and sales planning, budgeting of costs and sales prices, control of the fulfillment of planned results and profit, and regular reports on the economic situation of their company. It is clear from the results of the research that no large company participated in the survey, where lies possible future research. 


\section{References}

[1]. Stefko, R., Gallo, P., Matusikova, D., \& Molcak, T. (2019). Use of controlling in tourism sphere as a modern efficient management tool. In Bevanda \& Stetic (Eds.), Modern management tools and economy of tourism sector in present era (pp.509-526). DOI: $10.31410 /$ tmt.2019.509.

[2]. Valerian, L. (2017). The measurability of controlling performance. Вісник Киівського начіонального університету ім. Тараса Шевченка. Серія: Економіка, (2 (191)), 28-31.

DOI: 10.17721/1728-2667.2017/191-2/4.

[3]. Roehl-Anderson, J. M., \& Bragg, S. M. (2004). The controller's function: the work of the managerial accountant. John Wiley \& Sons.

[4]. Spickova, M., \& Myskova, R. (2015). Costs efficiency evaluation using life cycle costing as strategic method. Procedia economics and finance, 34, 337-343.

DOI: 10.1016/S2212-5671(15)01638-X.

[5]. Maidanevych, P. M., \& Prokopovych, L. B. (2010). Elements of Managerial Accounting Method. Actual Problems of Economics, (111), 265-271.

[6]. Vuko, T., \& Ojvan, I. (2013). Controlling and business efficiency. Croatian operational research review, 4(1), 44-52.

[7]. Nudurupati, S. S., Bititci, U. S., Kumar, V., \& Chan, F. T. (2011). State of the art literature review on performance measurement. Computers \& Industrial Engineering, 60(2), 279-290.

DOI: $10.1016 /$ j.cie. 2010.11.010.

[8]. Kupec, V., \& Pisar, P. (2021). Auditing and controlling as a tool for SME marketing risk management. Marketing and Management of Innovations, 12(1), 225-235.

DOI: $10.21272 / \mathrm{mmi} .2021 .1-17$.

[9]. Morales, J., \& Pezet, A. (2012). Financialization through hybridization: The subtle power of financial controlling. In Finance: The Discreet Regulator (pp. 19-39). Palgrave Macmillan, London.

DOI: 10.1057/9781137033604_2.

[10]. Sprinkle, G. B. (2003). Perspectives on experimental research in managerial accounting. Accounting, Organizations and Society, 28(2-3), 287-318.

DOI: $10.1016 / \mathrm{S} 0361-3682(01) 00058-7$

[11]. Bhosekar, S. K., \& Vyas, G. (2012). Cost controlling using earned value analysis in construction industries. International Journal of Engineering and Innovative Technology (IJEIT), 1(4), 324-332.

[12]. Rodríguez, R. C., Rivera, D. N., Bartutis, F. R., \& Rodríguez, M. L. (2015). Integration of management control tools. Analysis of a case study. Enfoque UTE, 6(3), 1-19

[13]. Bourne, M. C. S., Mills, J. F., Wilcox, M., Neely, A. D., \& Platts, K. W. (2000). Designing, implementing and updating performance measurement systems. International Journal of Operations and Production Management, 20, 754-771.

DOI: $10.1108 / 01443570010330739$.
[14]. Bititci, U., Garengo, P., Dörfler, V., \& Nudurupati, S. (2012). Performance measurement: challenges for tomorrow. International journal of management reviews, 14(3), 305-327.

DOI: $10.1111 / \mathrm{j} .1468-2370.2011 .00318 . x$.

[15]. Toni, A. D., \& Tonchia, S. (2001). Performance measurement systems-Models, characteristics and measures. International Journal of Operations \& Production Management, 21(1-2), 46-71. DOI: $10.1108 / 01443570110358459$.

[16]. Folan*, P., \& Browne, J. (2005). Development of an extended enterprise performance measurement system. Production Planning \& Control, 16(6), 531544. DOI: $10.1080 / 09537280500112355$

[17]. Gonos, J., Muchová, M., \& Domaracká, L. (2016). Controlling as an efficient tool for the strategic management of industrial companies. Acta montanistica slovaca, 21(3).

[18]. Pisar, P., \& Bilkova, D. (2019). Controlling as a tool for SME management with an emphasis on innovations in the context of Industry 4.0. Equilibrium. Quarterly Journal of Economics and Economic Policy, 14(4), 763-785.

[19]. Sedliacikova, M. (2014). Model of financial controlling. Annals of Warsaw University of Life Sciences-SGGW. Forestry and Wood Technology, 88 .

[20]. Idobayeva, A. (2020). Improvement Of The Enterprise Management System Based On Modern Principles Of Building Business Processes, Controlling And Risk Management. Three Seas Economic Journal, 1(3), 40-45. DOI: $10.30525 / 2661-5150 / 2020-3-7$.

[21]. Neely, A. (1999). The performance measurement revolution: why now and what next?. International Journal of Operations \& Production Management, 19(2), 205-228. DOI: $10.1108 / 01443579910247437$

[22]. Messner, M., Becker, C., Schäffer, U., \& Binder, C. (2008). Legitimacy and identity in Germanic management accounting research. European Accounting Review, 17(1), 129-159. DOI: $10.1080 / 09638180701819808$.

[23]. Mocanu, M. (2014). Towards a definition of controlling. Studies and scientific researches. Economics edition, (20). DOI: $10.29358 /$ sceco.v0i20.295.

[24]. Eccles, R. G. (1991). The performance measurement manifesto. Harvard business review, 69(1), 131-137.

[25]. Porter, J. K., Jarvis, P., Little, D., Laakman, J., Hannen, C., \& Schotten, M. (1996). Production planning and control system developments in Germany. International Journal of Operations \& Production Management, 16(1), 27-39. DOI: $10.1108 / 01443579610106346$.

[26]. Kruml, L., Novotny, J., \& Sejkora, F. (2015). Process Management in Interconnection to Business Controlling. In International Multidisciplinary Scientific Conference on Social Sciences and Arts SGEM 2015 (pp. 843-850). 
[27]. Mundy, J. (2010). Creating dynamic tensions through a balanced use of management control systems. Accounting, society, 35(5), 499-523.

DOI: $10.1016 /$ j.aos.2009.10.005

[28]. Schmiedel, T., Vom Brocke, J., \& Recker, J. (2014). Development and validation of an instrument to measure organizational cultures' support of Business Process Management. Information \& Management, 51(1), 43-56.

DOI: $10.1016 /$ j.im. 2013.08.005

[29]. Hammer, M., Vom Brocke, J., \& Rosemann, M. (2010). What is business process management? Handbook on business process management 1. are J. v. Brocke and M. Rosemann. Berlin, published in Springer.

[30]. Eldridge, S., van Iwaarden, J., van der Wiele, T., \& Williams, R. (2014). Management control systems for business processes in uncertain environments. International Journal of Quality and Reliability Management, 31(1), 66-81. DOI: 10.1108/IJQRM-03-2012-0040.

[31]. Plenkina, V. V., Taubayev, A., \& Lenkova, O. V. (2016). Management Tools of Cost Controlling at the Gas Transportation Enterprise. Journal of Internet Banking and Commerce, 21(S4).

[32]. Misheva, I. (2014). Controlling in the management of the Insurance Company. Nauchni trudove, (2), 6396.

[33]. Necheukhina, N. S., Gagarina, N. M., Shitova, T. F., \& Mukhanova, N. V. (2017, September). Information technologies of controlling as a factor of innovative development of telecommunication companies. In 2017 International Conference" Quality Management, Transport and Information Security, Information Technologies"(IT\&QM\&IS) (pp. 252259). IEEE. DOI: 10.1109/ ITMQIS.2017.8085806.
[34]. Gutierrez, D. M., Scavarda, L. F., Fiorencio, L., \& Martins, R. A. (2015). Evolution of the performance measurement system in the Logistics Department of a broadcasting company: An action research. International Journal of Production Economics, 160, 1-12. DOI: $10.1016 /$ j.ijpe.2014.08.012

[35]. Gosselin, M. (2005). An empirical study of performance measurement in manufacturing firms. International Journal of Productivity and Performance Management, 54(5-6), 419-437. DOI: $10.1108 / 17410400510604566$.

[36]. Gottlieb, U., Hansson, H., \& Johed, G. (2021). Institutionalised management accounting and control in farm businesses. Scandinavian Journal of Management, 37(2), 101153.

DOI: $10.1016 /$ j.scaman.2021.101153.

[37]. Heinicke, A. (2018). Performance measurement systems in small and medium-sized enterprises and family firms: a systematic literature review. Journal of Management Control, 28(4), 457-502. DOI: $10.1007 /$ s00187-017-0254-9.

[38]. CRIF. (2020). Financial statements of businesses, Slovak Credit Bureau, Bratislava. Retrieved from: www.crif.sk/firmy-a-podnikatelia/ [accessed: 10 October 2021].

[39]. Janošková, M., Čulková, K., \& Csikósová, A. (2018). Position and development of small and medium enterprises in European countries. In Proceedings of the $8^{\text {th }}$ Business \& Management conference, IISES- International Institute of Social and Economic Sciences, Venice, Italy, pp. 91-103. DOI: 10.20472/ BMC.2018.008.007. 